\title{
Congresso e Política de Reforma do Estado no Brasil*
}

\author{
Licínio Velasco Junior
}

\section{INTRODUÇÃO}

$\mathrm{O}$ s projetos do Executivo que visam implementar reformas estruturais enfrentam interesses cristalizados no status quo, não só por parte da oposição, como também de segmentos da sua base de coalizão. O objetivo deste artigo é entender como estes interesses são superados por meio de negociações que evitam a rejeição ou a transfiguração dos projetos. A metodologia utilizada para fundamentar as explicações sobre a implementação destas reformas e delas extrair conclusões mais gerais privilegia a análise das negociações entre o Executivo e o Legislativo, tomando por base o estudo de dois casos selecionados do primeiro mandato do governo Fernando Henrique Cardoso: a implementação da desestatização da Companhia Vale do Rio Doce CVRD e a produção legislativa que permitiu a desestatização do setor de telecomunicações.

\footnotetext{
*Este artigo constitui uma versão resumida de minha tese de doutorado em Ciência Política, defendida no Iuperj em 29 de abril de 2005, sob o título A Política Pública de Privatização no Presidencialismo de Coalizão Brasileiro. A alteração do título, de minha exclusiva responsabilidade, deve-se ao fato de que, embora a pesquisa da tese tenha se baseado na política pública de privatização, o modelo analítico proposto neste trabalho pode também ser testado, empiricamente, em outras políticas reformistas no contexto do presidencialismo de coalizão brasileiro, em seu passado recente. Agradeço os comentários do meu orientador, professor Fabiano Santos, e dos demais membros da banca, professores Maria Regina Soares de Lima, Eli Diniz, Maria Hermínia Tavares de Almeida e Renato Raul Boschi, bem como as contribuições dos pareceristas anônimos de Dados.
}

DADOS - Revista de Ciências Sociais, Rio de Janeiro, Vol. 49, n² 2, 2006, pp. 233 a 268. 
Argumenta-se que as privatizações ocorreram em um período em que o Executivo detinha, no que se refere a este tipo de política, graus de liberdade para impor estrategicamente sua preferência perante aquela correspondente à tendência central do Congresso Nacional, em um momento em que parte das tensões da negociação política do presidencialismo de coalizão se transferia para a atividade de fiscalização. Essas condições são tidas como necessárias - mas não necessariamente suficientes - à implementação destas políticas. Uma vez existentes tais condições, aos casos selecionados foi aplicado um modelo analítico de coordenação de interesses cuja construção se sustenta em duas arenas de negociação, partidária e distributiva, que interagem entre si. Durante as negociações, o Executivo foi tratado, analiticamente, como interdependente de sua base de coalizão, razão pela qual o termo Governo será utilizado para expressar o conjunto Executivo e sua base de coalizão parlamentar.

A forma de abordagem dos casos seguiu o caminho de uma narrativa analítica, em que são combinadas a história e a produção das políticas com a teoria da escolha racional, em consonância com o trabalho de Bates et alii (1998). A adoção da narrativa analítica para abordar os casos selecionados revelou-se consistente com o previsto pelos autores que a defendem, no sentido de que, na análise dos casos, ocorre uma contínua interação entre o material pesquisado e o modelo analítico assumido, o caráter dedutivo do modelo sendo informado pelo caráter indutivo da pesquisa dos casos.

Nos casos analisados, o Governo, embora tendo o apoio da maioria dos congressistas para a aprovação dos seus projetos, necessita negociar internamente, em sua base de coalizão. Isto ocorre porque a oposição não se propõe à cooperação na arena partidária, com a busca de políticas alternativas que pudessem ser julgadas viáveis pelo Governo. Internalizada a negociação dentro da coalizão, verifica-se a existência do parlamentar pivô da coalizão, aquele que mais provavelmente poderia votar contra os projetos do Governo. O parlamentar pivô será o objeto de maior atenção do Governo na arena distributiva. As negociações nesta arena permitem modificar o ganho deste parlamentar, levando-o a votar em sintonia com o projeto do Governo.

Embora reconhecendo a limitação das conclusões que possam ser extraídas da análise de somente dois casos, entende-se que o modelo analítico baseado na coordenação de interesses em duas arenas de negoci- 
ação revela-se adequado para a compreensão da produção de reformas conduzidas no âmbito do presidencialismo de coalizão brasileiro. Uma vez satisfeitas as condições necessárias de exeqüibilidade, nos termos argumentados, o sucesso na implementação das políticas é explicável pelas negociações desenvolvidas nas arenas partidária e distributiva.

\section{ORGANIZAÇÃO DO TRABALHO}

Inicialmente, apresenta-se uma síntese da literatura recente aplicável ao presidencialismo de coalizão brasileiro, em especial a que enfatiza os pontos institucionais de veto, com implicações negativas para a produção de políticas públicas no país, e a que privilegia a coordenação dos atores, com implicações positivas. Da análise sobre a política pública de privatizações no período pós-1985, constrói-se o argumento sobre as condições prévias de viabilidade das privatizações.

Na seqüência, são discutidas as condições de suficiência para o sucesso da implementação das reformas, por meio da proposição do modelo de análise baseado na coordenação de interesses dos atores envolvidos em duas arenas de negociação, uma partidária e outra distributiva. Tendo como referencial o modelo analítico proposto, para cada caso selecionado são destacadas as principais conclusões extraídas das respectivas narrativas analíticas ${ }^{1}$. Como consideração final, é apresentada uma implicação teórica julgada passível de avaliação empírica em outros casos.

\section{AS POLÍTICAS PÚBLICAS E 0 PRESIDENCIALISMO BRASILEIRO}

O objetivo desta seção é apresentar, resumidamente, a literatura recente aplicável ao presidencialismo de coalizão brasileiro, em especial: (1) a que enfatiza os pontos institucionais de veto para a produção de políticas públicas no país, com implicações negativas; e (2) a que privilegia a coordenação dos atores, com implicações positivas.

Um postulado geral da primeira vertente da literatura é o de que, quanto maior o número de vetos, menor a capacidade decisória, maior a estabilidade das políticas adotadas - leia-se maior a dificuldade de alteração do status quo - e maior a produção de políticas de caráter privado, por conta das negociações envolvendo pagamentos colaterais em políticas distributivas ${ }^{2}$, associados à superação dos vetos. É neste sentido que as implicações da configuração e do funcionamento das 
instituições políticas brasileiras para a produção de políticas de caráter nacional têm sido objeto de sistemática análise por parte desta literatura (Cox e McCubbins, 2001; Shugart e Haggard, 2001, entre outros).

O sistema partidário e eleitoral brasileiro induziria a uma maior produção de políticas de caráter privado, em razão da grande quantidade de partidos, de facções partidárias e de parlamentares que atuam de forma independente do partido. A fragmentação partidária - definida pela grande quantidade de partidos em competição no Legislativo - teria como decorrência um efeito perverso para a governabilidade, uma vez que, quanto maior a fragmentação legislativa, menor tende a ser o tamanho do partido do presidente. Gabinetes formados por coalizões partidárias são também vistos como possíveis causadores de mau desempenho econômico (Roubini e Sachs, 1989; Alesina, Roubini e Cohen, 1997).

Ademais, a estrutura política fragmentada e descentralizada do Brasil seria uma facilitadora da atuação de grupos de interesse - organizações empresariais e trabalhistas, em especial - na oposição às reformas econômicas (Haggard e Kaufman, 1995). A ausência de sindicatos abrangentes também funcionaria como impeditivo para o sucesso de políticas de ajustes de caráter estrutural, por não induzir à participação institucionalizada de grupos de interesse, como em alguns países da Europa (idem).

À separação de poderes - própria do presidencialismo - juntam-se, assim, outros aspectos institucionais que são, recorrentemente, considerados como entraves a que políticas de caráter reformista sejam implementadas no Brasil, em função do que representariam em termos de pontos de veto à produção de políticas nacionais que implicam a alteração do status quo: ausência de sindicatos abrangentes, estrutura federativa, governos de coalizão e fragmentação partidária.

Em síntese, para parte expressiva desta literatura, a configuração institucional brasileira tem sido vista, no mínimo, como geradora de dificuldades para a produção de políticas nacionais, o que significa dizer que, deste ponto de vista, os casos analisados neste artigo - a desestatização da CVRD e a reforma do setor de telecomunicações - seriam autênticos exemplos de políticas públicas no país errado.

Tomando-se por base a outra vertente da literatura, o debate transfere-se de uma visão centrada na não-governabilidade da democracia 
brasileira, em uma linha de indicação normativa de uma configuração institucional que leva à paralisia decisória, para uma análise dos mecanismos efetivos de funcionamento dessa democracia, ou seja, como se governa o Brasil à luz da sua configuração institucional (Palermo, 2000). Nesta linha, é enfatizada a capacidade de coordenação dos interesses dos diversos atores relevantes envolvidos no processo decisório político, condição para que as políticas de governo sejam implementadas. Essa outra vertente da literatura confere poder explicativo à análise das políticas que são produzidas no Brasil, a despeito dos pontos de veto. Isso não significa dizer que a configuração institucional de cada país não importa, mas, sim, que importa no sentido de implicar diferentes estratégias de coordenação por parte do Governo para atingir seus objetivos.

No caso dos regimes presidencialistas, as diferenças em suas configurações resultam em distintos padrões de cooperação ou de concorrência entre os poderes Executivo e Legislativo para a produção das leis (Shugart e Carey, 1992). Seguindo esse caminho, Figueiredo e Limongi (1999) analisaram o processo decisório do sistema político brasileiro sob a Constituição de 1988. Em oposição às teses que privilegiam as conseqüências danosas dos excessivos pontos de veto do sistema político brasileiro, estes autores sustentam que há mecanismos de governabilidade no presidencialismo de coalizão que se tem verificado no Brasil. Esta governabilidade estaria associada aos poderes constitucionais do presidente - legislativos, administrativos ou distributivos -, garantindo ao Executivo a capacidade de concentrar o processo decisório e de impor sua agenda. De outro lado, apesar da fragmentação partidária e do sistema eleitoral com lista aberta, Figueiredo e Limongi demonstram que, em face da existência de uma forte centralização dos trabalhos do Legislativo nos líderes partidários, não há a indisciplina partidária apregoada por parte da literatura. Em poucas palavras: partidos políticos importam no presidencialismo brasileiro.

Em trabalho posterior, entretanto, Ames (2001) reiteraria a percepção de ineficácia do sistema político brasileiro, com base na grande quantidade de atores com poder de veto, inerente à sua estrutura institucional, a ineficácia sendo fundamentalmente definida em função da manutenção do status quo.

As visões de Figueiredo e Limongi e de Ames não são necessariamente conflitantes quando pensadas em termos da dificuldade associada ao 
processo de negociação decisória, uma vez que Ames chama a atenção para o que não é produzido. A concentração de poderes no presidencialismo brasileiro de coalizão não resolveria, assim, por si só, a questão da incerteza do Executivo quanto a formular uma política que suponha tratamento legislativo. Neste sentido, não seria suficiente a verificação das disciplinas partidárias nas votações nominais de uma dada matéria que vai a plenário. Isto porque a disciplina partidária não significa, necessariamente, que os partidos da coalizão respondam disciplinadamente às iniciativas do Executivo, mas, sim, que a disciplina concede previsibilidade a acordos quando esses são firmados (Palermo, 2000).

Independentemente da abordagem das literaturas, não se pode negar que políticas públicas reformistas de caráter nacional não deixam de ser produzidas no país, e que existe no presidencialismo brasileiro um intenso processo de negociação entre os poderes Legislativo e Executivo, não totalmente captado quando são analisadas apenas as legislações aprovadas e as respectivas votações.

\section{AS PRIVATIZAÇÕES NO PERÍODO PÓS-1985 E O PRESIDENCIALISMO DE COALIZÃO BRASILEIRO}

Nesta seção, visa-se, inicialmente, justificar a escolha da privatização como a política reformista a ser objeto de análise para se extrair conclusões sobre o processo decisório do presidencialismo de coalizão brasileiro, para, em seguida, analisar-se o contexto que permitiu ao Executivo buscar sua implementação.

A escolha decorre, primeiro, das características desta política pública. As privatizações enquadram-se como reformas econômicas que envolvem custos concentrados no curto e médio prazos e benefícios difusos no longo prazo, em que a ação coletiva dos perdedores é facilitada pela clareza da perda com as reformas, as quais, de outro lado, projetam resultados incertos para a sociedade e seus mais diretos beneficiários. Privatizações não são as legislações de preferência dos parlamentares - aquelas que envolvem transferência concentrada de recursos (Santos, 1995) ${ }^{3}$-, sendo, portanto, políticas públicas em relação às quais se espera que haja negociação entre os dois poderes.

Segundo, porque a privatização, entre as mudanças que têm composto a agenda da reforma do Estado no Brasil, apesar dos benefícios difusos e da imposição de custos concentrados, foi uma das que mais avançou 
no período recente no país, o Estado tendo se retirado de setores que gerenciou com exclusividade por várias décadas (Pinheiro, 1999).

Foram selecionadas, como objeto de pesquisa, a desestatização da CVRD e a reforma do setor de telecomunicações, ambas levadas a efeito no primeiro mandato do governo Fernando Henrique Cardoso, por sua contemporaneidade e importância relativa. A CVRD foi escolhida por ser uma empresa estatal emblemática cuja privatização foi realizada em meio a expressivas manifestações de rejeição da sociedade. A reforma do setor de telecomunicações, em função de se tratar de um serviço público e pela profundidade da reestruturação do setor associada a esta desestatização. Por outro lado, apesar de situadas em uma mesma categoria, essas duas desestatizações são, na verdade, políticas públicas bastante distintas, que implicaram diferentes processos de negociação entre os poderes Executivo e Legislativo. Essa diferenciação é sintetizada no Quadro 1, ao final desta seção. Feitas essas observações, cabe expor, brevemente, o contexto geral de implementação das referidas reformas econômicas no país.

As reformas econômicas ocorridas nos países em desenvolvimento nas décadas de 1980 e 1990 têm sido amplamente discutidas na literatura, tendo em vista a compreensão sobre a transformação das idéias e das políticas que vigoravam nos anos 1970, baseadas no desenvolvimento calcado no Estado. Nesta literatura, o Brasil é situado entre aqueles países que só se moveram na direção de reformas estruturais ao final da década (Stallings, 1992, entre outros).

A despeito das privatizações realizadas no governo Sarney, elas só se tornam, de fato, parte da agenda pública no governo Collor, mais precisamente, a partir de 15 de março de 1990, quando é instituído o Programa Nacional de Desestatização - PND, por meio de medida provisória - MP, conferindo à privatização status de prioridade dentre as políticas de governo.

O fato de as privatizações se tornarem política de governo neste período não elimina a questão de como se forjaram as condições para sua implementação. Afinal, não só não havia consenso sobre a prioridade de reformas estruturais no período imediatamente anterior, como também Collor havia assumido o governo sem base partidária de apoio e sem o suporte de segmentos organizados da sociedade civil. As condições para a transformação de um sentimento difuso antiestatista, pre- 
sente em sua campanha eleitoral, em uma política de privatizações não estavam dadas (Schneider, 1990).

Com base em estudos realizados pelo Instituto de Desenvolvimento Econômico e Social do Planalto - IDESP em 1991 e 1995, com uma amostra das duas Casas, Tavares de Almeida e Moya (1997) avaliaram a posição do Congresso sobre as privatizações, revelando que a posição de absoluta adesão ao intervencionismo estatal prevalecente - definido como sendo o status quo - era minoritária no Legislativo pelo menos desde 1991. A maioria dos seus membros era, portanto, favorável a alguma mudança na forma de atuação do Estado. Mais ainda: dos sete maiores partidos com assento no Congresso, apenas em dois, somando cerca de 15\% das cadeiras na Câmara e 6\% no Senado, a maioria ou a totalidade dos parlamentares era a favor do status quo. De forma análoga, estudo realizado por Soares de Lima e Boschi em 1995 mostra que a posição totalmente favorável à intervenção do Estado representava, então, apenas $22,4 \%$ dos congressistas.

Desses estudos foram extraídas apenas as posições extremadas a favor do status quo, isso não significando dizer que a posição dominante fosse o seu oposto. Muito pelo contrário, as conclusões dos dois trabalhos indicam a prevalência de um reformismo moderado, quer por parte dos congressistas, quer por parte das elites em geral, não sendo crível que reformas estruturais pudessem ser implementadas sem a formação de coalizões que viessem a garantir a continuidade das mesmas.

Esta exposição é suficiente para inferir-se que à época em que as privatizações ganharam a prioridade do Executivo, no início dos anos 1990, a preferência do congressista mediano sobre o nível de intervenção do Estado na economia estava distante do status quo.

O'Halloran (1994), pesquisando sobre a área de comércio exterior dos Estados Unidos, em levantamento de dados que remonta ao século XIX, mostra como a ausência de interferência do Congresso não significa, necessariamente, aquiescência, podendo denotar, de outra forma, que o presidente é capaz de agir de modo a evitar a ação contrária do Congresso. Pode-se ter uma aparência enganosa de grande poder discricionário do presidente quando o status quo se encontra distante da preferência do congressista mediano. Nesse sentido, O'Halloran conclui que, quanto mais longe o status quo se coloca dessa preferência mediana, maior a liberdade do presidente para alterá-lo de acordo com as suas preferências, o inverso sendo também verdadeiro - quanto mais 
próximo o status quo se encontra do congressista mediano, menor a liberdade do presidente em aprovar uma nova política do seu interesse.

De outro lado, Santos e Patrício (2001), avaliando as bases da autonomia concedida ao Banco Central brasileiro, a partir da Constituição de 1988, argumentam que tensões do presidencialismo de coalizão no Brasil se transferem para a atividade de fiscalização do Executivo por parte do Legislativo. Sem negar que a perspectiva de transferência de responsabilidade $e^{4}$ e complexidade dos assuntos que envolvem a atuação do Banco Central sejam fatores de delegação ao Executivo, concluem os autores que o Legislativo transfere sua atenção e poder de interferência para a atividade de fiscalização, na qual as divergências dos partidos da coalizão ocorrem e são superadas por meio de acordos que envolvem o presidente e seu partido. A negociação política desloca-se, assim, para a atividade de fiscalização, que passa a ser o locus de rearranjos das bases de cooperação nos gabinetes.

Embora seja razoável supor que a transferência de parte das tensões do presidencialismo de coalizão para a atividade de fiscalização tenda a ocorrer mais fortemente nas políticas de natureza econômica que induzam a uma estratégia de transferência de responsabilidade, por força dos seus resultados imediatos, a exemplo da política monetária, isto não significa que este argumento não tenha validade, em algum nível, nas demais políticas públicas, desestatizações incluídas.

Desta exposição extraem-se dois argumentos básicos que permitem entender como foi possível ao Governo levar adiante a sua política de reformas. Esses argumentos constituem-se no pano de fundo sobre o qual ocorreram as negociações entre o Executivo e o Legislativo que possibilitaram a desestatização da CVRD e a reforma do setor de telecomunicações. São eles:

1) As privatizações, na década de 1990, ocorrem em um ambiente em que a preferência do congressista mediano sobre o nível de intervenção do Estado na economia encontrava-se distante do status quo. Nesse sentido, o Executivo tinha graus de liberdade para impor estrategicamente sua preferência sobre esta política, em relação àquela correspondente à tendência central do Congresso.

2) Parte das tensões do presidencialismo de coalizão transfere-se para a atividade de fiscalização, a qual se torna um locus de negociação política, onde partidos e parlamentares que competem eleitoralmente en- 
tre si buscam o rearranjo das suas bases de cooperação após a produção das políticas, independentemente do nível de cooperação da coalizão governamental para a produção dessas políticas. A possibilidade deste segundo turno de negociação facilita a delegação da base governista para o Executivo, o que não significa dizer que isto ocorra de forma absoluta e igual em todas as matérias.

Embora esses argumentos permitam compreender as condições que favoreceram a implementação das reformas, não explicam, por si só, o resultado da produção dessas políticas. Expressam condições de viabilidade prévia, necessárias, mas não suficientes. Falta analisar as preferências dos diversos atores envolvidos, como interagem entre si, e como se dá a coordenação destas preferências por parte do Governo. Essas análises são feitas por meio das narrativas analíticas aplicadas aos casos selecionados.

\section{MODELO DE ANÁLISE DAS NEGOCIAÇÕES ENTRE 0 EXECUTIVO E 0 LEGISLATIVO}

Apresentados os argumentos - condições necessárias - que fundamentam a viabilidade da busca da implementação da privatização por parte do Executivo, é proposto um modelo analítico que permite a compreensão das negociações dos casos estudados. Trata-se de elucidar as condições de suficiência para o sucesso da implementação das reformas por meio da proposição de um modelo de análise baseado na coordenação de interesses dos atores envolvidos.

As ênfases no caráter particularista-distributivo ou partidário da produção de políticas públicas ganharam corpo na década de 1990, com a formalização de estudos e modelos sobre o funcionamento do Legislativo norte-americano. De um lado, os que apregoavam que o sistema político americano implicaria a subprodução de políticas nacionais, com os benefícios das políticas se associando, geograficamente, aos distritos dos deputados. Neste sentido, o Congresso organizar-se-ia, institucionalmente, para atender os objetivos eleitorais dos parlamentares de forma individual, os partidos importando pouco como entidades aglutinadoras de interesses (Mayhew, 1974; Shepsle, 1978; Weingast e Marshall, 1983, entre outros). De outro lado, a vertente de pesquisa que indicava uma visão oposta, de que os partidos importam para os interesses individuais de reeleição dos parlamentares, a organização institucional do Congresso, nesse caso, sendo vista como ten- 
Quadro 1

Principais Características dos Casos Selecionados

\begin{tabular}{|c|c|c|}
\hline & Desestatização da CVRD & $\begin{array}{c}\text { Reforma do Setor de } \\
\text { Telecomunicações }\end{array}$ \\
\hline $\begin{array}{l}\text { 1) Legislações } \\
\text { Pertinentes }\end{array}$ & $\begin{array}{l}\text { 1) MP } 155 \text {, de 15/3/90, criando o } \\
\text { PND; } \\
\text { 2) Lei } 8.031 \text {, de 12/4/90 (PND), } \\
\text { oriunda da MP 155; } \\
\text { 3) Decreto 1.510, de 1/6/95, in- } \\
\text { cluindo a CVRD no PND. }\end{array}$ & $\begin{array}{l}\text { 1) EC nº 8, de 15/8/95, flexibili- } \\
\text { zando o monopólio estatal das } \\
\text { telecomunicações; } \\
\text { 2) Lei 9.295, de 19/7 /96 (Lei Mí- } \\
\text { nima), sobre regras de competi- } \\
\text { ção no serviço móvel celular; } \\
\text { 3) Lei 9.472, de 16/7/97 (Lei Ge- } \\
\text { ral das Telecomunicações - LGT), } \\
\text { dispondo, entre outros, sobre a } \\
\text { instituição do órgão regulador e } \\
\text { as condições para a reestrutura- } \\
\text { ção e privatização do setor de te- } \\
\text { lecomunicações. }\end{array}$ \\
\hline $\begin{array}{l}\text { 2) Locus prin- } \\
\text { cipal de ne- } \\
\text { gociação en- } \\
\text { tre o Executi- } \\
\text { vo e o Legis- } \\
\text { lativo }\end{array}$ & $\begin{array}{l}\text { Senado. } \\
\text { Papel relevante exercido pela } \\
\text { Comissão de Serviços de } \\
\text { Infra-Estrutura do Senado. }\end{array}$ & $\begin{array}{l}\text { Câmara. } \\
\text { Papel relevante exercido pelas } \\
\text { Comissões Especiais nos casos } \\
\text { da EC e LGT, e Comissão de } \\
\text { Ciência e Tecnologia, Comunica- } \\
\text { ção e Informática no caso da Lei } \\
\text { Mínima. }\end{array}$ \\
\hline $\begin{array}{l}\text { 3) Interesse } \\
\text { dos estados } \\
\text { da federação }\end{array}$ & $\begin{array}{l}\text { Bastante concentrado nos esta- } \\
\text { dos de Minas Gerais, Espírito } \\
\text { Santo, Pará, Maranhão, Bahia e } \\
\text { Sergipe, que se apresentavam } \\
\text { como os perdedores potenciais } \\
\text { com a venda da CVRD. }\end{array}$ & $\begin{array}{l}\text { Reação contrária difusa. } \\
\text { Perdedores dispersos e possibili- } \\
\text { dade de ganhos associados a no- } \\
\text { vos investimentos no curto e mé- } \\
\text { dio prazo. }\end{array}$ \\
\hline $\begin{array}{l}\text { 4) Possibili- } \\
\text { dade de utili- } \\
\text { zação das } \\
\text { empresas em } \\
\text { negociações } \\
\text { políticas }\end{array}$ & Reduzida. & $\begin{array}{l}\text { Alta, por meio de todo o siste- } \\
\text { ma: } 27 \text { empresas de telefonia } \\
\text { distribuídas por todos os esta- } \\
\text { dos da Federação e o Distrito Fe- } \\
\text { deral, a holding Telebrás e a } \\
\text { Embratel. }\end{array}$ \\
\hline $\begin{array}{l}\text { 5) Possibili- } \\
\text { dade de ne- } \\
\text { gociações la- } \\
\text { terais do Exe- } \\
\text { cutivo com } \\
\text { deputados da } \\
\text { base gover- } \\
\text { nista }\end{array}$ & $\begin{array}{l}\text { Pouco relevante, na medida em } \\
\text { que a Lei } 8.031 \text { conferia ampla } \\
\text { delegação para o Executivo e } \\
\text { que não havia mecanismos cla- } \\
\text { ros que permitissem intermedia- } \\
\text { ção por parte dos deputados. }\end{array}$ & $\begin{array}{l}\text { Bastante relevante para o proces- } \\
\text { so, por conta da existência de } \\
\text { amplos recursos de intermedia- } \\
\text { ção de interesses dos deputados } \\
\text { junto aos estados e municípios. }\end{array}$ \\
\hline
\end{tabular}

(continua) 
Quadro 1

Principais Características dos Casos Selecionados (continuação)

\begin{tabular}{|c|c|c|}
\hline & Desestatização da CVRD & $\begin{array}{l}\text { Reforma do Setor de } \\
\text { Telecomunicações }\end{array}$ \\
\hline $\begin{array}{l}\text { 6) Posição do } \\
\text { setor empre- } \\
\text { sarial, nacio- } \\
\text { nal e estran- } \\
\text { geiro }\end{array}$ & $\begin{array}{l}\text { Resistência, no geral. } \\
\text { Processo em que, de antemão, } \\
\text { poderia se prever um resultado } \\
\text { com pouquíssimos vencedores e } \\
\text { perdedores visíveis. }\end{array}$ & $\begin{array}{l}\text { Forte apoio, ainda que com a } \\
\text { existência de tensão nas empre- } \\
\text { sas situadas no universo da } \\
\text { Associação Brasileira da Indús- } \\
\text { tria Elétrica e Eltrônica - Abinee. } \\
\text { Processo que implicou múltiplos } \\
\text { vencedores e possibilidades de } \\
\text { novos negócios, bem como a } \\
\text { perspectiva de melhor atendi- } \\
\text { mento dos grandes usuários dos } \\
\text { serviços de telecomunicações. }\end{array}$ \\
\hline $\begin{array}{l}\text { 7) Posição } \\
\text { das corpora- } \\
\text { ções técnicas }\end{array}$ & $\begin{array}{l}\text { Grande resistência, com forte } \\
\text { apelo nacionalista. } \\
\text { Empresa estatal desde sua cons- } \\
\text { tituição. } \\
\text { Receio de demissões e da dilui- } \\
\text { ção da importância do papel da } \\
\text { empresa - a atuação da CVRD } \\
\text { passando a se subordinar aos in- } \\
\text { teresses das companhias dos } \\
\text { grupos empresariais vencedores. }\end{array}$ & $\begin{array}{l}\text { Resistência pulverizada, estreita- } \\
\text { mente coordenada pelo Ministé- } \\
\text { rio das Comunicações. } \\
\text { O Sistema Telebrás não era esta- } \\
\text { tal de origem. O monopólio esta- } \\
\text { tal só veio de fato a ser estabele- } \\
\text { cido a partir de Lei } 4.117 / 62 \text { e } \\
\text { consolidado pela Lei } 5.792 / 72 \text {, } \\
\text { atribuindo ao Sistema Telebrás a } \\
\text { exploração dos serviços públicos } \\
\text { de telecomunicações. A constitu- } \\
\text { cionalização desse monopólio só } \\
\text { ocorreu com a Carta de } 1988 \text {. } \\
\text { Apenas a Embratel, criada em } \\
\text { 16/9/65, foi constituída como } \\
\text { estatal, com feições estratégicas. }\end{array}$ \\
\hline $\begin{array}{l}\text { 8) Posição } \\
\text { dos sindica- } \\
\text { tos de traba- } \\
\text { lhadores }\end{array}$ & $\begin{array}{l}\text { Fortemente contrária, com apelo } \\
\text { nacionalista. Receio de demis- } \\
\text { sões, da diluição da importância } \\
\text { do papel da empresa e de que a } \\
\text { CVRD se tornasse centro de cus- } \\
\text { tos dos grupos empresariais ven- } \\
\text { cedores. }\end{array}$ & $\begin{array}{l}\text { Reação bastante dificultada, na } \\
\text { medida em que se previam sig- } \\
\text { nificativos acréscimos de investi- } \\
\text { mentos, contrabalançando os re- } \\
\text { ceios de demissões. } \\
\text { Papel fundamental exercido pela } \\
\text { Lei Mínima, permitindo a licita- } \\
\text { ção imediata das concessões dos } \\
\text { serviços móveis celulares da } \\
\text { Banda B, que resultariam em no- } \\
\text { vos investimentos e empregos, } \\
\text { sem demissões. }\end{array}$ \\
\hline
\end{tabular}

(continua) 
Quadro 1

Principais Características dos Casos Selecionados (continuação)

\begin{tabular}{|c|c|c|}
\hline & Desestatização da CVRD & $\begin{array}{c}\text { Reforma do Setor de } \\
\text { Telecomunicações }\end{array}$ \\
\hline $\begin{array}{l}\text { 9) Posição da } \\
\text { sociedade ci- } \\
\text { vil em geral }\end{array}$ & $\begin{array}{l}\text { Grande resistência, com forte } \\
\text { apelo nacionalista. Empresa per- } \\
\text { cebida como estatal eficiente e } \\
\text { tendo caráter emblemático, em } \\
\text { função de suas atividades, liga- } \\
\text { das ao subsolo nacional. } \\
\text { Preocupação das comunidades } \\
\text { situadas nas áreas de maior in- } \\
\text { fluência da CVRD. }\end{array}$ & $\begin{array}{l}\text { Apoio, ainda que difuso. } \\
\text { Serviços considerados precários } \\
\text { e insuficientes, além de atingir } \\
\text { apenas os segmentos mais favo- } \\
\text { recidos da sociedade. }\end{array}$ \\
\hline $\begin{array}{l}\text { 10) Coorde- } \\
\text { nação do Exe- } \\
\text { cutivo }\end{array}$ & $\begin{array}{l}\text { Não concentrada, dificultando a } \\
\text { coordenação. O órgão decisório } \\
\text { do PND era um colegiado com- } \\
\text { posto por diversos ministros de } \\
\text { Estado. }\end{array}$ & $\begin{array}{l}\text { Forte concentração no Ministério } \\
\text { das Comunicações. } \\
\text { A privatização das telecomuni- } \\
\text { cações não se vinculava ao PND. }\end{array}$ \\
\hline $\begin{array}{l}\text { 11) Interesse } \\
\text { do Ministério } \\
\text { da Fazenda }\end{array}$ & $\begin{array}{l}\text { Forte, pela sinalização do com- } \\
\text { prometimento do novo governo } \\
\text { com reformas estruturais. }\end{array}$ & $\begin{array}{l}\text { Muito forte. Não só pela sinali- } \\
\text { zação do comprometimento com } \\
\text { reformas estruturais, como tam- } \\
\text { bém pelo valor de arrecadação } \\
\text { esperado e pela expectativa de } \\
\text { forte presença de investidores } \\
\text { estrangeiros, com a conseqüente } \\
\text { entrada de recursos externos. }\end{array}$ \\
\hline $\begin{array}{l}\text { 12) Valores } \\
\text { arrecadados } \\
\text { nos leilões }\end{array}$ & $\begin{array}{l}\text { US\$ 3,132 - arrecadação total- } \\
\text { mente em moeda corrente local; } \\
\text { vencedores foram investidores } \\
\text { nacionais. }\end{array}$ & $\begin{array}{l}\text { Banda B (Lei Mínima): US\$ 7,613 } \\
\text { Telefonia fixa, longa distância e } \\
\text { Banda A: US\$ 18,944 } \\
\text { Total: US\$ 26,557 - cerca de } 60 \% \\
\text { dos recursos arrecadados em } \\
\text { moeda estrangeira. }\end{array}$ \\
\hline
\end{tabular}

do um desenho capaz de atender os desejos do partido majoritário e seus líderes (Kiewiet e McCubbins, 1991; Cox e McCubbins, 1993).

Alguns trabalhos posteriores, na literatura americana, questionariam a suposta incompatibilidade dos modelos distributivo e partidário. Shepsle e Weingast (1995) propuseram que as pesquisas deveriam ser enriquecidas com modelos híbridos que levassem em consideração, de forma simultânea, a premissa distributiva das preferências e o papel de coordenação exercido pelas instituições em proveito de uma produ- 
ção legislativa mais coletiva. Epstein e O'Halloran (1999), por sua vez, argumentaram que as abordagens deveriam ser vistas como complementares e não excludentes entre si, uma vez que diferentes legislações requerem estruturas diversas de processo decisório, nenhuma das teorias sendo suficiente para abranger todos os casos e situações. Carvalho (2003) segue uma linha similar para o estudo do comportamento legislativo no Brasil, com base na premissa de que o Legislativo brasileiro demanda solução teórica interativa que combine os modelos partidário e distributivo.

A construção do modelo analítico apresentado neste artigo parte da mesma premissa utilizada por Carvalho. Na explicação das políticas públicas produzidas, o caráter distributivo do sistema político-eleitoral brasileiro, que levaria ao bloqueio da produção de políticas nacionais, de acordo com Ames (2001), é aceito como parte integrante do processo decisório, bem como a visão de Figueiredo e Limongi (1999) sobre o papel de coordenação exercido pelos partidos.

Por fim, a questão indicada por Palermo (2000), abordada anteriormente, sobre o real significado das votações, é automaticamente incorporada, uma vez que o que se quer explicar é a produção de políticas públicas por parte do Governo, entendido como o Executivo e sua base de coalizão parlamentar, o que abrange as negociações desenvolvidas.

\section{AS DUAS ARENAS DE NEGOCIAÇÃO DAS POLÍTICAS PÚBLICAS}

Postula-se que a produção das políticas públicas brasileiras seja inteligível à luz das negociações entre os poderes Executivo e Legislativo e que estas negociações se desenvolvem em duas arenas, uma partidária e outra distributiva. À arena partidária associam-se os interesses do Governo em relação à política que se pretende aprovar ou implementar. À arena distributiva associam-se os interesses subnacionais e eleitorais particulares dos parlamentares julgados relevantes para a aprovação da política pública desejada. Estas arenas, na situação mais geral, interagem entre si, podendo ou não ocorrer em um mesmo locus de negociação.

Esta estrutura analítica não significa que ao Governo não interesse reduzir ao máximo os custos distributivos, o que sugere que a arena distributiva se desenvolve na medida em que há a percepção de que a arena partidária é insuficiente para a aprovação da política desejada. Tão 
logo esta percepção emerge, as negociações nas arenas partidária e distributiva tendem a se dar de forma simultânea e interativa.

São utilizados conceitos da teoria da escolha racional para explicar as configurações das políticas públicas engendradas interativamente pelas arenas partidária e distributiva, o que se justifica na medida em que a identidade dos diversos atores, seus objetivos e preferências podem ser estabelecidos e as regras de interação são conhecidas pelos agentes (Tsebellis, 1990).

As análises dos casos selecionados, que amparam empiricamente o modelo de análise proposto, seguiram o caminho de uma narrativa analítica. A narrativa analítica é um conceito que combina a história e a produção das políticas com a teoria da escolha racional. São identificados os agentes envolvidos - atores individuais ou coletivos -, suas preferências e os fundamentos de suas escolhas e decisões em nível micro, os caminhos evitados e os efetivamente adotados, bem como as formas pelas quais as escolhas resultam em fatos e se revertem em decisões políticas, buscando-se uma interação permanente entre o modelo analítico assumido e a pesquisa realizada, as idéias sendo confrontadas continuamente com a realidade (Bates et alii, 1998). Por construção, a narrativa analítica implica o cruzamento entre as literaturas sobre a importância dos grupos de interesse para a produção de políticas públicas e aquelas que analisam o comportamento do Legislativo por meio das votações.

As preferências dos agentes são, entretanto, passíveis de serem mediadas por instituições capazes de coordená-las, no sentido de induzir a resultados Pareto-Ótimo ${ }^{5}$ superior, em que todos fiquem em melhores condições. O conflito entre as racionalidades individuais e coletivas é, assim, resolvido por meio de instituições capazes de facilitar a comunicação entre os agentes, realçando e tornando críveis os benefícios para os cooperadores e os custos para os desertores (Tsebellis, 1990).

Como parte integrante da narrativa analítica, na busca do entendimento dos resultados finais das negociações entre o Executivo e o Legislativo, são ainda investigadas políticas simultâneas ou quase-simultâneas, também negociadas em arenas partidárias e distributivas, as quais, dedutivamente, tenham exercido influência naquela que está sendo objeto de apreciação, reforçando a perspectiva de sua implementação. Assume-se que essa será uma análise fundamentalmente contrafactual, significando dizer que, caso essas políticas não tives- 
sem existido, a probabilidade de implementação da política desejada se reduziria até o limite do seu insucesso. A simultaneidade destas políticas é o que permite um caráter dedutível consistente, na medida em que sejam eventos próximos com mecanismos causais bem compreendidos, sujeitos a poucas interferências de outros eventos externos (Fearon, 1996).

É fato que, na condução das políticas de natureza econômica do interesse do Executivo, há predominância da preferência do presidente, ao qual, como reconhecido na literatura, em função de possuir eleitorado nacional, é concedida delegação objetivando a superação dos dilemas de ação coletiva associados aos conflitos distributivos decorrentes dos interesses de reeleição dos congressistas. No entanto, a extensão desta delegação dependerá da maior ou menor proximidade entre as preferências do presidente e as do Congresso, como visto anteriormente (O'Halloran, 1994; Epstein e O'Halloran, 1999), ou, mais especificamente, entre as preferências do presidente e as de sua base de coalizão. O exercício dessa delegação pelo presidente se faz, todavia, com subdelegações para seus ministros e líderes partidários, para atuarem nas arenas partidária e distributiva, com vista a garantir a aprovação da política.

As comissões congressuais funcionam como o locus natural da arena partidária, ainda que não exclusivo, uma vez que a escolha de parlamentares para integrá-las está centralizada nas mãos dos líderes partidários. As comissões reúnem os parlamentares mais experientes e com expertise nas matérias que nelas tramitam, além de propiciar maior participação individual, por conta da menor restrição ao uso da palavra eà apresentação de emendas (Figueiredo e Limongi, 1999; Santos, 2002). Uma vez a política tendo sido votada nas comissões, é submetida ao plenário, onde a ação dos líderes e as negociações desenvolvidas buscam permitir sua aprovação de acordo com os interesses do Executivo e sua coalizão.

Na coordenação dos diversos interesses, o Governo conta com atores-chave, chamados por Arnold (1979; 1990) de líderes de coalizão, aqueles que influenciam e conduzem a estruturação do processo decisório congressual, por serem capazes de antecipar as decisões de voto dos parlamentares, seja nas comissões, seja em plenário. Em princípio, mas não exclusivamente, os líderes de coalizão naturais são o presidente, 
o ministro a cujo Ministério esteja vinculada a política proposta e os líderes partidários.

Nas comissões, o relator aparece como outro líder de coalizão fundamental. Cabe a ele apresentar o projeto substitutivo ao original, incorporando propostas dos parlamentares. Contudo, há uma enorme diferença entre o que os parlamentares propõem e o que é incorporado ao projeto pelos relatores. A participação dos congressistas é filtrada, limitando a participação individual no que se refere a propostas próprias que atendam a seus interesses particulares (Figueiredo e Limongi, 1999). Isso não significa que a proposta do relator não expresse demandas de grupos de interesse. Ao contrário, a comissão é o locus apropriado de expressão desses interesses, até por conta da identificação dos parlamentares que nela atuam e da especialização em relação à matéria em apreciação, o que, em alguma medida, os vincula a setores econômico-sociais e grupos de interesse (Santos, 2002). Entretanto, esses interesses são mediados pelos líderes partidários, os quais se encontram em condições de propor alterações ao status quo, em conjunto com o relator, além ou aquém das preferências dos grupos de interesse. Esta percepção se sintoniza com o caso norte-americano, em acordo com a referida pesquisa de O'Halloran (1994) sobre a área de comércio exterior dos Estados Unidos.

Ao relator cabe, portanto, a função de ajustar os projetos vindos do Executivo, de forma a ampliar a perspectiva de cooperação por parte dos parlamentares, aprovando uma proposta que busque unir a coalizão governamental na comissão, antes de seguir para plenário, onde a maior pulverização de interesses será, em algum nível, mediada pela arena distributiva. O Executivo, subsidiado pelos líderes de coalizão no mapeamento de interesses particulares que possam colocar em risco a aprovação da política desejada, detém recursos para garantir apoio à sua proposta. Isto inclui os recursos de patronagem, expressão usualmente utilizada para a concessão de postos em cargos no Executivo, e as denominadas legislações pork-barrel ${ }^{6}$, que visam atender interesses eleitorais dos parlamentares, principalmente aquelas que não necessitam de autorização do Legislativo (Santos, 1997; Amorim Neto e Santos, 2001; Pereira e Mueller, 2002; Santos, Machado e Rocha, 1996).

Quando a coalizão governista é maioria, como no período de produção das políticas que serão objeto de análise empírica, a previsão é que as negociações se transfiram para o seu interior, ainda que informadas 
pela preferência da oposição. Quando a coalizão governista não é maioria, a negociação se amplia em termos de participantes, o que não altera a natureza do problema: trata-se de buscar uma proposta que, ao mesmo tempo em que una a base governista, atraia parte da oposição, até se atingir o quórum necessário para a aprovação da matéria. Pode-se antever que, no presidencialismo de coalizão, a negociação será totalmente internalizada na base governista quando a oposição tiver a preservação do status quo como estratégia dominante ${ }^{7}$. Quando a oposição aceita negociar alternativas, nada impede que ela seja encarada como mais um membro da coalizão para aquela política específica, capaz de causar à política proposta tantos embaraços ou benesses quanto a base governista.

Postula-se, ainda, que este modelo de análise tenha validade para a Câmara e o Senado. Dependendo das características e especificidades das políticas, o centro principal de tensão e negociação tende a ocorrer de forma mais evidente em uma das duas casas legislativas. A diferença básica é que, no Senado, atores estaduais - governadores, políticos e grupos de interesse locais - se farão presentes como sinalizadores dos interesses subnacionais, na medida em que o Senado, no Brasil, é desenhado para representar os estados. Tendo em vista que senadores e deputados são eleitos no Brasil por sistemas eleitorais distintos - sistemas majoritário e de representação proporcional, respectivamente-, o que altera são as fontes dos interesses. Uma vez que as negociações entre o Executivo e o Legislativo não ocorrem desvinculadas dos interesses outros da sociedade, em especial aqueles dos grupos organizados, tanto o Executivo como o Legislativo, durante a negociação, encontram-se informados sobre esses interesses, vocalizados por meio do mecanismo denominado na literatura de alarme de incêndio ${ }^{8}$ e mediados pelos líderes de coalizão do governo.

\section{O MODELO DE DUAS ARENAS E OS CASOS ANALISADOS}

O objetivo desta seção é apresentar a forma de aplicação do modelo aos casos empíricos selecionados: a desestatização da CVRD e a produção legislativa que permitiu a desestatização do setor de telecomunicações, ambos ocorridos no primeiro mandato do governo Fernando Henrique Cardoso.

O primeiro caso, o que parecia ser apenas a implementação de uma política em relação à qual o Executivo detinha ampla delegação. O segun- 
do, a produção de três marcos regulatórios, um dos quais uma emenda constitucional, que resultaria em profundas alterações no status quo. No caso da CVRD, o foco principal de tensão e negociação ocorreu no Senado; no das telecomunicações, na Câmara.

Os dois casos se dão em um contexto em que o Governo é representado por uma coalizão que lhe fornece maioria para aprovar essas políticas e a oposição não participa das negociações, uma vez que sua estratégia dominante é a preservação do status quo. Ocorre, entretanto, que no interior da coalizão governamental existem parlamentares que não estão completamente convencidos dos benefícios das reformas pretendidas.

No caso da CVRD, estes parlamentares se encontram entre os senadores do Partido do Movimento Democrático Brasileiro - PMDB e os senadores da coalizão vinculados às regiões de influência - doravante denominadas como RIs - desta companhia: Minas Gerais, Espírito Santo, Maranhão, Sergipe, Bahia e Pará. Na reforma do setor de telecomunicações, estes parlamentares são deputados do PMDB.

Mais especificamente, em relação aos parlamentares do PMDB, estes representam o parlamentar mediano, de tradição nacionalista, deste partido, conceito extraído do "Teorema do Eleitor Mediano", apresentado por Hinich e Munger (1997), relativo a quando se está diante de uma única dimensão política - no caso, a privatização - e há preferência por uma escolha - não privatizar ou privatizar - em relação à outra. A existência deste parlamentar mediano nacionalista do PMDB - na desestatização da CVRD e na reforma do setor de telecomunicações -, para o qual se dirige a oposição na busca de uma aliança para frustrar os projetos do Governo, é objeto de demonstração empírica nas narrativas analíticas dos dois casos selecionados.

Em seu conjunto, os parlamentares não completamente convencidos podem ser considerados, para efeito de análise, como um ator unitário, visto como sendo o pivô, cujo posicionamento pode - com maior probabilidade do que qualquer outro grupo de parlamentares - causar transtornos aos objetivos do Governo.

O Governo não só sabe da existência destes parlamentares como também não desconhece que a atitude racional de cada um, individualmente, é votar contra as reformas pretendidas. Na medida em que a oposição não coopera, será, principalmente, com o pivô que o Governo terá de estabelecer as bases de negociação. Presumivelmente, a sua re- 
jeição à política proposta poderia, ainda, deflagrar votos contrários de outros parlamentares não-pivôs da coalizão do Governo.

Utilizando a teoria dos jogos, Tsebellis (1990) mostra que existem jogos secundários, que se desenvolvem enquanto se desenrolam os jogos principais, que alteram os resultados - payoffs - destes últimos. Como conseqüência, os payoffs que são aceitos pelos participantes do jogo principal só fazem sentido quando se consideram os de jogos secundários, jogados pelos mesmos participantes. Em poucas palavras: os jogos secundários alteram os resultados dos principais, tornando-os explicáveis e racionais.

No modelo de análise adotado, em analogia à visão de Tsebellis, o jogo principal desenvolve-se na arena partidária, e o secundário, na distributiva. A decisão do pivô em apoiar a reforma - arena principal - só é totalmente compreendida caso também seja considerada a arena distributiva. O Governo e o pivô - tratados analiticamente como atores unitários - são os jogadores que, estrategicamente, buscam o melhor resultado para si, até se chegar à solução Pareto-Ótimo para ambos, o que, em última instância, sintetiza a razão da aprovação da política.

\section{PRINCIPAIS CONCLUSÕES EXTRAÍDAS DA NARRATIVA ANALÍTICA SOBRE A IMPLEMENTAÇÃO DA DESESTATIZAÇÃO DA CVRD}

Um primeiro ponto a ser destacado é que a análise dos projetos do Governo apenas com base no resultado final da sua implementação pode dizer pouco sobre a extensão das negociações entre os poderes Executivo e Legislativo.

Na implementação da desestatização da CVRD, à primeira vista se estava diante de um caso em que o Executivo, gozando de ampla delegação, por conta da Lei no 8.031, de 12 de abril de 1990 - lei que regula o Programa Nacional de Desestatização, oriunda de MP -, simplesmente teria dado curso aos seus desejos, não tomando conhecimento de demandas do Legislativo e de outros segmentos da sociedade.

Todavia, a ausência de um processo explícito e institucionalizado de discussão entre o Executivo e o Legislativo quando da produção de políticas públicas legisladas com o auxílio de MPs não induz o Legislativo ao comprometimento com estas políticas. O Legislativo passa a atuar na margem, acionado, na maior parte das vezes, por meio de grupos de interesse organizados, quando das reedições das MPs. 
De fato, apesar da delegação ao Executivo por meio de lei, o assunto desestatização da CVRD não havia sido discutido no Legislativo. Essa discussão terminaria por ocorrer quando a CVRD foi incluída no PND. As negociações que se desenvolvem entre os dois Poderes demonstram que, para determinadas políticas públicas, em especial aquelas que não provocam alteração instantânea do status quo, mesmo a medida provisória permite a ação do Legislativo (Amorim Neto e Tafner, 2001). E isto se evidencia não apenas nas alterações processadas na Lei no 8.031/90, mas, também, na própria implementação da desestatização da CVRD, em que os interesses da sociedade, e mais particularmente os de um grupo de estados da Federação, se encarregaram de acionar o mecanismo de alarme de incêndio, provocando intervenções por parte do Legislativo, a despeito de o Executivo dispor de ampla delegação, nos termos da Lei no 8.031/90.

Um outro aspecto de caráter geral a ser destacado é que projetos apresentados pelo Legislativo referentes às políticas do Executivo, mesmo que não sejam sequer votados, podem dizer muito das negociações entre esses poderes, não se tratando necessariamente - ou apenas - de uma estratégia de tomada de posição por parte de parlamentares que desejam se proteger perante seus eleitores (Mayhew, 1974). Ou seja, a análise dos projetos vencidos ajuda a entender o conteúdo do projeto vencedor. De fato, no caso da CVRD, estes projetos são de fundamental importância para se compreender o processo de construção do acordo entre o Executivo e sua coalizão parlamentar.

A coalizão que elegeu o presidente em 1994 era composta apenas pelo Partido da Social Democracia Brasileira - PSDB, o Partido da Frente Liberal - PFL e o Partido Trabalhista Brasileiro - PTB. Esta coalizão se amplia rapidamente: de janeiro de 1995 a abril de 1996, o gabinete do governo tinha representantes do PSDB, PMDB, PFL e PTB, e de abril de 1996 a dezembro de 1998, do bloco PSDB-PMDB-PFL-PTB-Partido Progressista Brasileiro - PPB-Partido Popular Socialista - PPS (Amorim Neto, 2000).

Tomando-se por base as eleições de 1994 e a coalizão ampliada de abril de 1996, o governo detinha o apoio de cerca de $80 \%$ dos senadores, $62 \%$ dos deputados e $80 \%$ dos governadores. A partir de abril, com a adesão do PPB, o governo estava numericamente preparado, inclusive, para alcançar os $3 / 5$ de quórum nas duas casas do Congresso, necessários para assegurar o seu programa de reformas constitucionais (Nicolau, 
1996; 2000). Importa notar que, no Senado, esta posição não dependia das adesões do PPB e do PPS. Sem estes partidos, a representação da coalizão nesta Casa situava-se em $74 \%$. A posição amplamente majoritária da coalizão governista, contudo, não permitiu, por si só, que a implementação da desestatização da CVRD fosse pacífica.

Primeiro, porque o Legislativo detinha - ou deteria durante o processo - informações que diferenciavam a desestatização da CVRD de outras antes realizadas, fossem estas informações de domínio público ou transmitidas por grupos de interesse. Estas informações, no essencial, derivaram dos seguintes fatos: (a) a CVRD era uma empresa emblemática e estatal desde sua criação, ligada à Era Vargas; (b) o processo decisório do PND era, desde sua criação, baseado em um sistema colegiado, permitindo a vocalização de divergências no interior do próprio Executivo; (c) o modelo adotado para a venda da CVRD era excludente quanto ao número de vencedores possíveis; e (d) a CVRD era uma empresa com atividades econômicas e sociais concentradas em alguns estados da federação, facilitando a ação coletiva por parte dos senadores dos estados tidos como perdedores com a privatização.

Segundo, porque, conforme discutido anteriormente, no presidencialismo de coalizão brasileiro esta negociação pode se dar dentro da coalizão parlamentar do Governo. Na medida em que a oposição tenha a manutenção do status quo como estratégia dominante, essa negociação tende a ser integralmente internalizada na base governista.

Na desestatização da CVRD, isto ocorre como previsto, tendo o Senado como locus central de negociações entre o Governo e sua coalizão. As negociações foram internalizadas na coalizão porque a posição do bloco de oposição era única, qual seja, a de não alteração do status quo. A defesa do status quo por parte da oposição é, entretanto, utilizada pela base governista na sua negociação, a partir da apresentação do Projeto 161/95, do senador José Eduardo Dutra (PT-SE), que objetivava restringir a delegação concedida ao Executivo, com conseqüência imediata para o caso da CVRD.

Tendo o Governo decidido pela negociação, a disposição em negociar sobre a forma de desestatização da CVRD torna-se crível quando é mediada pelo Legislativo, por intermédio da Comissão de Infra-Estrutura. 
Presentes as condições de viabilidade prévia mencionadas, o Governo teve êxito em implementar a sua política porque foi capaz de coordenar os interesses da sua base de coalizão, a despeito da forte pressão contrária de segmentos da sociedade e dos parlamentares da oposição, esta entendida, essencialmente, como o bloco PT-PDT-PSB-Partido Comunista do Brasil - PCdoB.

Em consonância com o modelo analítico apresentado, esta coordenação de interesses se baseou, fundamentalmente, na identificação dos senadores da coalizão tidos como pivôs e na negociação por meio de arenas partidárias e distributivas, tornando possível a implementação da desestatização da CVRD. São resumidos, a seguir, os principais pontos que amparam esta afirmação:

1. A concentração das atividades da CVRD em determinados estados (Minas Gerais, Espírito Santo, Maranhão, Sergipe, Bahia e Pará), denominados RIs, induziu, de fato, a uma atuação mais ativa de parlamentares oriundos desses estados, contrários ao projeto do Executivo. Todas as intervenções legislativas da coalizão captadas na pesquisa realizada - relativas a projetos que pretendiam alterar, em algum nível, a delegação dada ao Executivo pela Lei no 8.031 - vieram de parlamentares vinculados às RIs.

2. Em relação aos pronunciamentos contrários ao projeto do Governo, foi notória a concentração nos parlamentares das RIs, na Câmara do Deputados e no Senado, sobressaindo, inclusive, os da coalizão governamental. Embora a Câmara não tenha sido o locus central de negociação, exerceu o papel de vocalizar os interesses subnacionais e os da sociedade, uma vez que, do ponto de vista dos parlamentares da oposição, a reação da sociedade era uma grande arma. Este fato permitia que estes parlamentares buscassem, em última instância, o bloqueio do processo de desestatização da CVRD por intermédio do Poder Judiciário, o que quase veio a ocorrer.

3. No Senado, o PMDB foi identificado como o partido que mais provavelmente poderia se aliar à oposição para uma eventual tentativa de criar obstáculos à privatização da CVRD. Era deste partido que se esperava uma maior resistência, em face da existência de parlamentares de tradição nacionalista, permitindo antever o seu parlamentar mediano como sendo desta tradição. A análise das transcrições das atas das reuniões no Senado permite afirmar que é a este parlamentar que a oposição apela na defesa do status quo. Ademais, o PMDB detinha não só 22 
cadeiras no Senado, das quais 3 dos estados situados nas RIs, como também posições estratégicas nas comissões de Constituição, Cidadania e Justiça e de Assuntos Econômicos, comissões dominadas por senadores do $\mathrm{PMDB}$ de posição contrária à privatização da CVRD.

4. Em conseqüência, existiam dois focos de parlamentares pivôs, entendidos como aqueles cujo posicionamento poderia ser decisivo para o resultado de uma eventual votação contra a privatização da CVRD ou em favor da retirada de delegação ao Executivo: entre os vinculados às RIs e entre os senadores do PMDB, em especial o parlamentar mediano nacionalista deste partido.

5. A negociação com estes parlamentares, nos termos do modelo analítico, transcorre nas duas arenas: (a) na arena distributiva, principalmente com os parlamentares vinculados às RIs, em face da defesa dos interesses subnacionais associados ao próprio desenho do Senado, de representação dos estados; e (b) na arena partidária, principalmente com os parlamentares medianos nacionalistas do PMDB, em face da situação de desconforto com a desestatização da CVRD'.

No conjunto, estes parlamentares formavam um ator coletivo de 14 senadores da coalizão nas RIs e 19 senadores do PMDB, excluídos os 3 desse partido nas RIs ${ }^{10}$. Esses 34 senadores, agregados aos 13 da oposição (incluídos os que estão dentro e fora das RIs), totalizavam 47, um bloco com potencial de resistência superior ao de metade mais um dos 81 senadores.

6. As bases da negociação com os senadores pivôs são estabelecidas na Comissão de Infra-Estrutura, ao ser avaliado substitutivo para projeto proposto pelo senador José Eduardo Dutra. O senador Vilson Kleinübing (PFL-SC), na qualidade de relator desta comissão, torna-se, na estruturação dessa negociação, um crucial líder de coalizão do Governo.

7. As condições gerais de venda da companhia estabelecidas na Comissão de Infra-Estrutura demonstraram-se passíveis de serem decompostas em condições ligadas às duas arenas, partidária e distributiva, $\mathrm{e}$ foram incorporadas ao edital de venda da CVRD, produzido pelo Executivo. Foram atendidos interesses associados aos dois focos de parlamentares pivôs, citando-se, como exemplos: (a) antecipação de recursos para investimentos sociais nas RIs que seriam desembolsados ao longo do tempo pela CVRD, como empresa estatal (arena distributiva); e (b) participação da União nos resultados das operações associadas à 
exploração futura de novas descobertas em que a CVRD, na condição de empresa privada, fosse titular de direitos de pesquisa antes da privatização (arena partidária).

8. Havia uma outra arena partidária relevante que, dedutivamente, reforçava a possibilidade de implementação da privatização da CVRD, induzindo os pivôs à cooperação. Esta arena partidária - desenvolvida em paralelo à privatização da CVRD - se associava ao objetivo do Governo de manter a estabilidade cambial, base de sustentação do Plano Real, o que, em conseqüência, permitiria maior capital político para a reeleição presidencial. A privatização da CVRD cumpre o papel de sinalizar aos investidores externos o comprometimento do Governo com as reformas de mercado, o que não só possibilitaria maior volume de captação externa, como situaria o Governo em melhores condições para outros projetos, a reforma do setor de telecomunicações sendo o mais evidente deles, já expressamente presente na agenda pública. Esta arena partidária adicional colocava o Ministério da Fazenda como um decisivo aliado das privatizações ${ }^{11}$.

9. Por fim, no Ministério da Fazenda estrutura-se outra arena com alcance distributivo que, também dedutivamente, reforçava a possibilidade de implementação da privatização da CVRD. Os recursos políticos detidos por este ministério, que, à época, se encontrava envolvido no Programa de Reestruturação e Ajuste Fiscal dos Estados ${ }^{12}$, permitiam ampla coordenação do Governo sobre os interesses subnacionais dos senadores não ligados às RIs, em especial aqueles objeto de maior preocupação, tidos como pivôs, do PMDB. Esta outra arena distributiva tornava improvável que o conflito na implementação da privatização da CVRD extrapolasse os seis estados situados nas RIs.

PRINCIPAIS CONCLUSÕES EXTRAÍDAS DA NARRATIVA ANALÍTICA SOBRE A PRODUÇÃO LEGISLATIVA QUE PERMITIU A REFORMA DO SETOR DE TELECOMUNICAÇÕES

As conclusões mais gerais obtidas da análise da implementação da desestatização da CVRD permanecem válidas:

1. A análise dos projetos do Executivo apenas com base no resultado final da sua implementação pode dizer pouco sobre a extensão das negociações entre os poderes Executivo e Legislativo. Embora o Governo tenha logrado aprovar as legislações que permitiram a reforma pretendida, isto não se deu à revelia dos interesses do Legislativo e de outros 
segmentos da sociedade, em particular do setor de telequipamentos instalado no país.

2. O fato de a coalizão governista ser amplamente majoritária, em número suficiente para a aprovação, inclusive, da emenda constitucional que flexibilizou o monopólio estatal no setor de telecomunicações, não impediu, por si só, que os projetos oriundos do Executivo viessem a sofrer alterações no Congresso. As negociações que acarretaram estas alterações foram internalizadas na coalizão, ainda que sinalizadas e influenciadas pela posição do bloco de oposição. Assim como no caso da CVRD, a análise dos projetos vencidos ajuda a entender o conteúdo dos projetos vencedores.

3. Na desestatização da CVRD, estando presentes as condições de viabilidade prévia, o Governo teve êxito em implementar a sua política por ter sido também capaz de coordenar os interesses da sua base de coalizão. Em consonância com o modelo analítico apresentado, esta coordenação de interesses se baseou, no fundamental, na identificação dos parlamentares da coalizão tidos como pivôs e na negociação por meio de arenas partidárias e distributivas.

Se na desestatização da CVRD o Senado foi o locus central de negociação, na reforma do setor de telecomunicações este locus foi a Câmara. Nos dois casos há um pivô comum, o parlamentar mediano nacionalista do PMDB, senador no caso da CVRD e deputado na reforma do setor de telecomunicações. A análise das atas das reuniões das comissões parlamentares nas quais tramitaram os projetos da reforma do setor de telecomunicações, bem como das discussões em plenário, não deixa dúvida de que era, principalmente, este deputado pivô que a oposição buscava atrair para apoiá-la na defesa do status quo.

Assim como os senadores pivôs no caso da CVRD, estes deputados formavam, no conjunto, um ator coletivo cujo posicionamento poderia causar transtornos aos objetivos do Governo, notadamente em relação ao projeto da Lei Geral das Telecomunicações - LGT. Utilizando o ano de 1995 como referência, este ator coletivo seria constituído, no limite, por 107 deputados do PMDB (Nicolau, 1996). Em contraposição, o núcleo mais coeso do Governo era composto, à época, por 62 deputados do PSDB e 89 do PFL - total de 151 -, aos quais se acrescentariam 52 deputados do PPB, partido que, em razão da suas posições políticas históricas, não deveria apresentar dissidências significativas. Os 31 deputados do PTB também tenderiam a se alinhar, em sua maioria, ao Go- 
verno, em que pese ter em seus quadros alguns parlamentares de viés nacionalista. De outro lado, o bloco de oposição PT-PDT-PCdoB-PSB, partidos que sistematicamente votavam em conjunto, era composto, à época, por 108 deputados. Em resumo, abstraindo-se de eventuais dissidências no restante da coalizão (234 votos no total), o bloco de oposição e o PMDB detinham um potencial de 215 votos, tornando previsível que se desenvolvessem negociações entre o Governo e sua base parlamentar de sustentação, em especial os pivôs, nas arenas partidária e distributiva.

O foco principal da narrativa analítica sobre a reforma do setor de telecomunicações recaiu no setor de telefonia, preocupação central dos congressistas.

No contexto das negociações entre o Executivo e sua coalizão, os seguintes aspectos se revelavam, previamente, favoráveis à reforma: (a) o antecedente histórico dos serviços de telecomunicações, até a década de 1960, era de atendimento à população de forma pulverizada e por operadoras privadas. Somente a Embratel constituía-se, desde sua fundação, em uma empresa estatal com feição monopolista, desempenhando funções que poderiam ser consideradas como estratégicas para o país. A caracterização estatal dos serviços de telecomunicações só se consolidaria na Constituição de 1988; (b) os serviços prestados pelo Sistema Telebrás em todo país no início do governo Fernando Henrique Cardoso eram notoriamente precários.

Durante a implementação das reformas, os seguintes aspectos favoreceram seu êxito: (a) o processo decisório da reforma do setor foi fortemente concentrado em uma única entidade do Executivo, o Ministério das Comunicações; (b) este ministério foi capaz de exercer uma estreita e sistemática coordenação sobre a corporação do Sistema Telebrás, facilitado pelo fato de a Embratel ser dissonante em relação às demais empresas de telefonia distribuídas pelo país; (c) o projeto de emenda constitucional que flexibilizava o monopólio estatal implicava a imediata abertura do setor para novos investimentos no serviço de telefonia celular Banda B. A implementação desta abertura se revestia de característica totalmente atípica, uma vez que sinalizava uma reforma sem perdedores. Esta perspectiva, viabilizada pela denominada Lei Mínima, viria exercer um papel crucial na construção de apoio ao projeto de reforma do setor; (d) a forma de implementação da licitação de outorgas de concessão do serviço de telefonia móvel celular na Banda B sinaliza- 
va, desde cedo, em contraste com as privatizações do setor ocorridas no México e na Argentina, que no Brasil seria adotado um modelo que implicaria a existência de múltiplos vencedores; e (e) o Governo, por meio do Ministério das Comunicações, mobilizou de forma crível uma ampla rede de apoio de diferentes grupos beneficiários das reformas, ao longo da tramitação no Congresso dos projetos da emenda constitucional - EC no 08/95 -, da Lei Mínima e da Lei Geral das Telecomunicações.

De outro lado, conspiravam contra a aprovação da reforma: (a) o fato de o Sistema Telebrás, como estatal, representar papel ímpar de locus de negociação política; e (b) a existência de dois focos de tensão identificáveis na reforma do setor, associados à possibilidade de serem excluídos dos seus benefícios: a indústria de equipamentos de telecomunicações instalada no país e o Centro de Pesquisa e Desenvolvimento em Telecomunicações - CPqD, centro de capacitação tecnológica da Telebrás.

Foi comentado que demandas dos grupos de interesse são mediadas pelos líderes de coalizão do Governo que se encontram em condições de propor alterações ao status quo, sejam além ou aquém das preferências dos grupos de interesse.

A mediação dos dois aspectos mencionados como problemáticos para a implementação da reforma teria seus principais canais de negociação nas duas arenas do modelo analítico. De um lado, o ministro das Comunicações - líder de coalizão natural do Executivo na reforma - detinha recursos significativos para compensar ou atenuar os impactos, nos políticos da coalizão, pela perda do Sistema Telebrás como locus de negociação e de acomodação de interesses. De outro, as demandas associadas à indústria de equipamentos de telecomunicações instalada no país e à preservação do $\mathrm{CPqD}$ seriam objeto da arena partidária durante a tramitação da LGT.

A arena partidária de negociação teve na Câmara o seu locus principal quando das tramitações dos projetos de emenda constitucional, da Lei Mínima e da LGT. Nos projetos de emenda constitucional e da LGT, as negociações foram estruturadas em comissões especiais; no da Lei Mínima, na Comissão de Ciência e Tecnologia, Comunicação e Informática - CCTCI. Os relatores destas comissões constituíram-se em importantes líderes de coalizão do Governo. 
Conforme mencionado, o projeto da Lei Mínima, que permitia a licitação das outorgas de concessão da Banda B do serviço móvel celular, desempenhou um papel crucial nas negociações das legislações que compuseram a reforma do setor de telecomunicações. O serviço móvel celular Banda B apresentava-se como um bem público gerador de empregos e que visava ao provimento adicional de um serviço notoriamente prestado de forma insuficiente pelo Estado. Neste sentido, suas conseqüências imediatas tinham apoio nos mais diversos segmentos da sociedade, não sendo, conseqüentemente, uma legislação que pudesse ser caracterizada como danosa aos objetivos eleitorais de nenhum parlamentar da coalizão. Neste projeto, o poder de negociação do pivô era reduzido. Apesar de ter sido considerado controverso em sua legalidade e constitucionalidade desde sua origem, mesmo por parlamentares pertencentes ao eixo da coalizão governamental, os líderes de coalizão do Governo, diante de um projeto que não feria interesses dos parlamentares, foram capazes de forjar uma lei, estruturada na CCTCI, que ampliava a liberdade do Executivo para implementá-lo, não obstante a polêmica que seria travada no Congresso sobre seu escopo.

O conteúdo deste projeto teria reflexos nos dois outros projetos da reforma. Primeiro, em relação ao da emenda constitucional. A justificativa principal desta emenda, de flexibilização do monopólio estatal, era justamente permitir a imediata licitação do serviço móvel Banda B, uma vez que, nesta época, a desestatização do Sistema Telebrás ainda não era apresentada como projeto de Governo, o que só ocorreria depois, por meio do projeto da LGT. Ou seja, a emenda constitucional e a Lei Mínima faziam parte de um mesmo projeto, passível de justificar a posição do pivô perante seus eleitores. Segundo, em relação ao projeto da LGT. Por um lado, com a aprovação da Lei Mínima, o Governo conferia credibilidade ao projeto de reforma do setor, consolidando sua rede de apoio e intensificando a mobilização de interesses empresariais para o projeto maior da LGT. Por outro, havia flancos nesta rede de apoio, relacionados à indústria de telequipamentos, ao estímulo ao desenvolvimento tecnológico do setor e à preservação do $\mathrm{CPqD}$ como centro de capacitação tecnológica.

Existindo estes flancos, o parlamentar pivô da coalizão, de tradição nacionalista, que na Lei Mínima viu reduzido seu poder de negociação, retorna fortalecido à arena partidária de negociação quando da tramitação do projeto da LGT. Neste percurso, a oposição buscaria atrair o parlamentar pivô da coalizão defendendo a tese de que a continuidade 
do Sistema Telebrás como estatal era condição necessária para que pudessem ser preservados o parque industrial de telequipamentos instalado no país e a tecnologia desenvolvida no CPqD. Para evitar a adesão do pivô à tese da oposição, o substitutivo do relator da comissão especial constituída para apreciar o projeto da LGT incorporaria artigos que objetivavam atender os interesses não-contemplados no projeto vindo do Executivo, relativos à indústria de telequipamentos, ao estímulo ao desenvolvimento tecnológico do setor e à preservação do CPqD.

Caso o pivô ainda não se sentisse atendido pelas negociações nas arenas partidárias, o ministro das Comunicações, por meio do seu ministério, detinha recursos significativos na arena distributiva para induzi-lo ao apoio da reforma, a exemplo das outorgas para a exploração dos serviços de radiodifusão de sons e imagens, de serviços de $\mathrm{RTV}^{13} \mathrm{e}$ de radiodifusão comunitária. Em linguagem de teoria dos jogos, seguindo a linha discutida, esta arena distributiva se encarregaria de modificar o payoff do pivô nas arenas partidárias, de forma a obter sua cooperação.

Por fim, assim como na desestatização da CVRD, é deduzido que outras arenas partidárias e distributivas, que ocorrem fora do âmbito da reforma pretendida, reforçam a perspectiva de sua implementação. Estas arenas, em conjunto com as anteriores, complementam os payoffs dos pivôs, sua totalização representando, como construção analítica, o que seria o preço real da sua cooperação.

Na vertente principal da arena partidária situada fora do âmbito da reforma, repete-se para o setor de telecomunicações o argumento apresentado no caso da CVRD, sobre a sua importância para o projeto de reeleição do Governo, vinculada à manutenção da estabilidade da relação cambial dólar-real, base do Plano Real. A diferença é que as licitações das outorgas da Banda B e a desestatização do Sistema Telebrás representavam não só uma sinalização para o investidor externo, de comprometimento com reformas voltadas para o mercado, mas também uma entrada efetiva e substantiva de recursos externos.

Na vertente principal da arena distributiva situada fora do âmbito da reforma do setor de telecomunicações, esta arena se confunde com a anteriormente apresentada, associada aos recursos detidos pelo Ministério das Comunicações para atender os interesses eleitorais dos 
congressistas, os pivôs em especial, por meio das legislações pork-barrel.

\section{CONSIDERAÇÃO FINAL}

As conclusões extraídas das narrativas analíticas dos casos selecionados constituíram-se no objeto deste artigo. Todavia, destas conclusões decorre, ainda, uma implicação teórica, julgada passível de avaliação empírica em outros casos.

No desenvolvimento das negociações, quando a figura de um pivô é detectada dentro da coalizão, tem-se a seguinte expectativa: caso a oposição decida cooperar, no sentido de negociar alterações no âmbito da política proposta, abandonando a posição única de preservação do status quo, a arena distributiva torna-se menos crucial, com conseqüente redução dos custos associados à governabilidade do presidencialismo de coalizão brasileiro. Isto porque, neste caso, a importância do pivô da coalizão não só se reduz, como também o pivô, como membro da coalizão, ver-se-á na situação de proteger a política proposta de alterações na arena partidária que a transfigurem de forma substancial. O parlamentar pivô, ao perder poder de negociação na arena distributiva, será instado a atuar na arena partidária em maior sintonia com os demais membros da coalizão, para que não seja percebido pelo Governo como estando fora desta coalizão.

(Recebido para publicação em setembro de 2005)

(Versão definitiva em maio de 2006)

\section{NOTAS}

1. Na tese, as narrativas dos dois casos são apresentadas extensivamente e se encerram com apêndices, nos quais é utilizado o ferramental da teoria dos jogos para uma formalização simplificada das negociações, com o intuito de, fundamentalmente, realçar a lógica destas negociações.

2. Políticas que geram benefícios concentrados e custos dispersos.

3. Como regra, estas são legislações que atendem redutos eleitorais dos parlamentares, permitindo negociação entre eles de forma contínua: parlamentares apóiam projetos 


\section{Licínio Velasco Junior}

em que possuem menor interesse em troca de apoio futuro para projetos que desejam com mais intensidade.

4. Blame-shifting no original. A transferência de responsabilidade associa-se aos custos político-eleitorais das legislações (Mayhew, 1974, entre outros).

5. Um resultado é dito como sendo Pareto-Ótimo quando não existe a possibilidade de um agente melhorar sua condição sem reduzir as dos outros agentes (Tsebellis, 1990).

6. Legislações de caráter distributivo, na medida em que concentram benefícios nos distritos eleitorais dos parlamentares e repartem seus custos de forma dispersa.

7. Reproduzindo a linguagem utilizada em teoria dos jogos, conceitua-se estratégia dominante como sendo aquela que não se altera, independentemente da ação do outro agente ou jogador (Dutta, 2000).

8. A expressão alarme de incêndio decorre da assimetria de informação dos parlamentares em relação à burocracia. Os parlamentares são supridos de informação por meio da reação e intervenção dos grupos interessados que se sentem prejudicados (McCubbins e Schwartz, 1987).

9. A palavra principalmente é aqui realçada para chamar a atenção para o fato de que esta separação é uma construção analítica, não significando dizer que essas arenas não possam atender também aos demais parlamentares da coalizão. Todavia, para efeito da análise, importa a preocupação do governo com os pivôs, que são mais propensos à defecção. Essas arenas também não devem ser consideradas como atendendo de forma excludente cada pivô. Ou seja, alguns pivôs podem se considerar atendidos por negociações nas duas arenas.

10. Os 22 senadores do PMDB representavam $34 \%$ dos senadores da coalizão e $27 \%$ do total.

11. Ver Hahm, Hawlet e Mowery (1996) para uma visão dos efeitos positivos para a produção de políticas públicas decorrentes do papel de coordenação exercido por burocracias fiscais fortes.

12. Ver Rigolon e Giambiagi (1999) para uma exposição detalhada sobre o assunto.

13. Retransmissão dos sinais das estações geradoras de televisão para localidades onde os sinais não chegam diretamente ou chegam em condições precárias. 


\section{Congresso e Política de Reforma do Estado no Brasil}

\section{REFERÊNCIAS BIBLIOGRÁFICAS}

ALESINA, Alberto, ROUBINI, Nouriel e COHEN, Gerald. (1997), Political Cycles and the Macroeconomy. Cambridge, MIT Press.

AMES, Barry. (2001), The Deadlock of Democracy in Brazil. Michigan, University of Michigan Press.

AMORIM NETO, Octavio. (2000), “Gabinetes Presidenciais, Ciclos Eleitorais e Disciplina Legislativa no Brasil”. Dados, vol. 43, no 3. eSANTOS, Fabiano. (2001), “A Conexão Presidencial: Facções Pró e Antigoverno e Disciplina Partidária no Brasil”. Dados, vol. 44, № 2.

e TAFNER, Paulo. (2001), "Governos de Coalizão e Mecanismos de Alarme de Incêndio no Controle Legislativo das Medidas Provisórias". Dados, vol. 45, no 1.

ARNOLD, R. Douglas. (1979), Congress and the Bureaucracy: A Theory of Influence. New Haven, Yale University Press.

(1990), The Logic of Congressional Action. New Haven/London, Yale University.

BATES, Robert, GREIF, Avner, LEVI, Margaret, ROSENTHAL, Jean Laureant e WEINGAST, Barry. (1998), Analytical Narratives. Princeton, Princeton University Press.

CARVALHO, Nelson Rojas de. (2003), E no Início Eram as Bases: Geografia Política do Voto e Comportamento Legislativo no Brasil. Rio de Janeiro, Revan.

COX, Gary W. e MCCUBBINS, Mathew D. (1993), Legislative Leviathan: Party Government in the House. California, University of California Press.

. (2001), "The Institutional Determinants of Economic Policy Outcomes", in S. Haggard e M.D. McCubbins (eds.), Presidents, Parliaments, and Policy. New York, Cambridge University Press.

DUTTA, Prajit K. (2000), Strategies and Games: Theory and Practice. Cambridge, MIT Press.

EPSTEIN, David e O'HALLORAN, Sharyn. (1999), Delegating Powers: A Transaction Cost Politics Approach to Policy Making under Separate Powers. New York, Cambridge University Press.

FEARON, James D. (1996), “Causes and Counterfactuals in Social Science: Exploring an Analogy between Cellular Automata and Historical Processes", in P. E. Tetlock e A. Belkin (eds.), Counterfactual Thought Experiments in World Politics: Logical, Methodological and Psychological Perspectives. Princeton, Princeton University Press.

FIGUEIREDO, Argelina C. e LIMONGI, Fernando. (1999), Executivo e Legislativo na Nova Ordem Constitucional. Rio de Janeiro, Fundação Getulio Vargas Editora.

HAGGARD, Stephen e KAUFMAN, Robert R. (1995), The Political Economy of Democratic Transitions. Princeton, Princeton University Press.

HAHM, Sung Deuk, HAMLET, Mark S. e MOWERY, David C. (1996), “The Political Economy of Deficit Spending in Nine Industrialized Parliamentary Democracies: The Role of Fiscal Institutions". Comparative Political Studies, no 29. 


\section{Licínio Velasco Junior}

HINICH, Melvin J. e MUNGER, Michael C. (1997), Analytical Politics. Cambridge, Cambridge University Press.

KIEWIET, Roderick e MCCUBBINS, Mathew. (1991), The Logic of Delegation: Congressional Parties and the Appropriations Process. Chicago, University of Chicago Press.

MAYHEW, David R. (1974), Congress: The Electoral Connection. New Haven, Yale University Press.

MCCUBBINS, Matthew e SCHWARTZ, Thomas. (1987), "Congressional Oversight Overlooked: Police Patrols versus Fire Alarms", in M. McCubbins e T. Sullivan (orgs.), Congress: Structure and Policy. Cambridge, Cambridge University Press.

NICOLAU, Jairo Marconi. (1996), Multipartidarismo e Democracia: Um Estudo sobre o Sistema Partidário Brasileiro (1985-94). Rio de Janeiro, Fundação Getulio Vargas Editora.

(2000), “Disciplina Partidária e Base Parlamentar na Câmara dos Deputados no Primeiro Governo Fernando Henrique Cardoso (1995-1998)". Dados, vol. 43, no 4.

O'HALLORAN, Sharyn. (1994), Politics, Process and American Trade. Ann Arbor, The University of Chicago Press.

PALERMO, Vicente. (2000), “Como se Governa o Brasil? O Debate sobre Instituições Políticas e Gestão de Governo". Dados, vol. 43, no 3.

PEREIRA, Carlos e MUELLER, Bernardo. (2002), “Comportamento Estratégico em Presidencialismo de Coalizão: As Relações entre Executivo e Legislativo na Elaboração do Orçamento Brasileiro". Dados, vol. 45, № 2.

PINHEIRO, Armando Castelar. (1999), "Privatização no Brasil: Por Quê? Até Onde? Até Quando?", in F. Giambiagi e M. M. Moreira (orgs.), A Economia Brasileira nos Anos 90. Rio de Janeiro, BNDES.

RIGOLON, Francisco e GIAMBIAGI, Fabio. (1999), “A Renegociação das Dívidas e o Regime Fiscal dos Estados", in F. Giambiagi e M. M. Moreira (orgs.), A Economia Brasileira nos Anos 90. Rio de Janeiro, BNDES.

ROUBINI, Nouriel e SACHS, Jeffrey. (1989), "Political and Economic Determinants of Budget Deficits in the Industrial Democracies". European Economic Review, no 33.

SANTOS, Fabiano. (1995), "Clientelismo como Escolha Racional”, in E. Reis, M. H. Tavares de Almeida e P. Fry (orgs.), Pluralismo, Espaço Social e Pesquisa. São Paulo, Hucitec.

. (1997), “Patronagem e Poder de Agenda na Política Brasileira”. Dados, vol. 40, no3.

. (2002), "Partidos e Comissões no Presidencialismo de Coalizão". Dados, vol. 45, no 2 .

e PATRÍCIO, Inês. (2001), Moeda e o Poder Legislativo no Brasil: Um Estudo da Prestação de Contas de Bancos Centrais no Presidencialismo de Coalizão. Rio de Janeiro, Iuperj. Manuscrito.

SANTOS, Maria Helena C., MACHADO, Érica e ROCHA, Paulo E. N. M. (1996), “O Jogo Orçamentário da União: Relações Executivo-Legislativo na Terra do Pork-Barrel", in E. Diniz e S. Azevedo (orgs.), Reforma do Estado e Democracia no Brasil. Brasília, Editora da UnB/ENAP.

SCHNEIDER, Ben Ross. (1990), Privatization in the Collor Government: Triumph of Liberalism or Collapse of the Developmental State? Princeton, Princeton University Press. 


\section{Congresso e Política de Reforma do Estado no Brasil}

SHEPSLE, Keneth. (1978), The Giant Puzzle: Democratic Assignments in the Modern House. Chicago, University of Chicago Press.

e WEINGAST, Barry. (1995), "Positive Theories of Congressional Institutions", in K. Shepsle e B. Weingast (eds.), Positive Theories of Congressional Institutions. Ann Arbor, The University of Michigan Press.

SHUGART, Matthew Soberg e CAREY, John M. (1992), Presidents and Assemblies: Constitutional Design and Electoral Dynamics. New York, Cambridge University Press.

SHUGART, Matthew Soberg e HAGGARD, Stephen. (2001), "Institutions and Public Policy in Presidential Syistems", in S. Haggard e M. D. McCubbins (eds.), Presidents, Parliaments, and Policy. New York, Cambridge University Press.

SOARES DE LIMA, Maria Regina e BOSCHI, Renato. (1995), "Democracia e Reforma Econômica: A Visão das Elites Brasileiras". Dados, vol. 38, no 1.

STALLINGS, Barbara. (1992), “International Influence on Economic Policy: Debt, Stabilization, and Structural Reform", in S. Haggard e R. Kaufman (eds.), The Politics of Economic Adjustment: International Constraints, Distributive Conflicts and the State. Princeton, Princeton University Press.

TAVARES DE ALMEIDA, Maria Hermínia e MOYA, Maurício. (1997), “A Reforma Negociada: O Congresso e a Política de Privatização". Revista Brasileira de Ciências Sociais, vol. 12 , no 34 .

TSEBELLIS, G. (1990), Nested Games: Rational Choice in Cooperative Politics. Los Angeles, University of California Press.

WEINGAST, Barry e MARSHALL, William. (1983), "The Industrial Organization of Congress or Why Legislatures Like Firms Are Not Organized as Markets?". Journal of Political Economy, vol. 96. 
ABSTRACT

This article seeks to contribute to understanding how and under what conditions agreements are made between the Executive and Legislative Branches in the production of structural reforms in Brazil. The negotiations between the two powers are analyzed through two cases of privatization policy in the first term of the Fernando Henrique Cardoso Administration. The cases are approached through an analytical narrative combining history and policymaking with the rational choice theory. A theoretical model based on coordination of interests is applied to the cases, based on two interacting areas of negotiation: partisan and distributive.

Key words: coalition Presidentialism; analytical narrative; state reform; privatization

\section{RÉSUMÉ}

Congrès et politique de réforme de l'État au Brésil

Dans cet article, on cherche à montrer comment et dans quelles conditions, au moment de réformes structurelles au Brésil, s'établissent des accords entre les pouvoirs exécutif et législatif. Les négociations entre ces pouvoirs sont analysées à l'aide de deux épisodes de privatisation survenus pendant le premier mandat du président Fernando Henrique Cardoso. La démarche adoptée est celle d'un récit analytique où se combinent l'histoire et la production des politiques avec la théorie du choix rationnel. Aux deux cas choisis, on a appliqué un modèle analytique de coordination d'intérêts, bâti sur deux scènes de négociation, celle des partis et la distributive, qui interagissent entre elles.

Mots-clé: système présidentiel de coalition; récit analytique; réforme de l'État; privatisation 